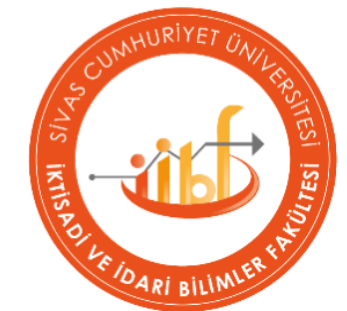

\title{
DYNAMIC INTEGRATION AND SEGMENTATION AMONG EQUITY MARKETS OF OECD COUNTRIES
}

\section{Mustafa ÇAYIR ${ }^{1}$}

\begin{abstract}
The purpose of this study is to explore that the direction in which the dependency among the equity markets of Organisation for Economic Cooperation and Development (OECD) countries has progressed over time and how it was affected by the subprime mortgage 2008 global financial crisis. Within this framework, integration and segmentation among the equity markets of OECD countries have been investigated in this study. The study covers 2000:01 - 2018:12 period and the method of feasible generalized least square is used in the econometric estimation. The subprime mortgage 2008 global financial crisis has affected the level of integration negatively while the passing of time influences the integration level positively among the equity markets according to the obtained results in this study. In addition, the current integration responds to its own lagged values positively. In conclusion, it can be said that the integration phenomenon feeds itself-vice versa.
\end{abstract}

Article History:

Date submitted:

29 May 2020

Date accepted:

10 March 2021

Jel Codes:

G15, F36, G01

Keywords:

Integration, Segmentation, Stock Markets, OECD

Countries, Financial Crisis

Suggested Citation: Çayır, M. (2021). Dynamic Integration and Segmentation Among Equity Markets of OECD Countries. Sivas Cumhuriyet University Journal of Economics and Administrative Sciences, 22(1), 196-212.

${ }^{1}$ Dr. Öğr. Üyesi, Mustafa ÇAYIR, Artvin Çoruh Üniversitesi, Uygulamalı Bilimler Yüksekokulu, Bankacılık ve Finans Bölümü, mustafacayir@artvin.edu.tr,_ORCID ID: 0000-0001-8744-631X 
Sivas Cumhuriyet Üniversitesi

İktisadi ve İdari Bilimler Dergisi

E-ISSN: 2687-4032

2021, 22 (1), ss. 196-212.

Doi: 10.37880/cumuiibf.745241

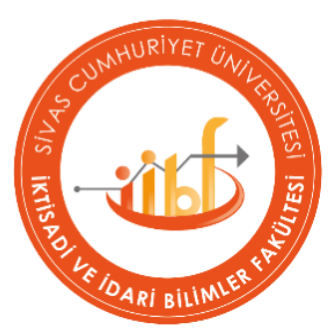

\section{OECD ÜLKELERI HISSE SENEDI PIYYASALARI ARASINDAKI DİNAMIK ENTEGRASYON VE SEGMENTASYON}

\section{Mustafa ÇAYIR ${ }^{1}$}

$\ddot{O} z$

Bu çalışmanın amacl, Ekonomik Kalkınma ve İş Birliği Örgütü ülkelerinin hisse senedi piyasaları arasındaki bağlllı̆̆ın zamanla ne yöne doğru yol aldığını ve 2008 mortgage küresel finansal krizinden nasıl etkilendiğini ortaya koymaktır. Bu kapsamda çalışmada, Ekonomik Kalkınma ve Işs Birliği Örgütü'ne üye ülkelerin hisse senedi piyasalarl arasindaki entegrasyon ve segmentasyon incelenmektedir. Çalışma, 2000:01 - 2018:12 dönemini kapsamaktadır ve çalışmanın ekonometrik tahminlemesinde uygulanabilir genelleştirilmiş en küçük kareler yöntemi kullanılmıştır. Çalışmada elde edilen sonuçlara göre, 2008 mortgage küresel finansal krizi hisse senedi piyasalart arasındaki entegrasyonu negatif etkilerken, zaman değişkeni entegrasyon seviyesini pozitif etkilemektedir. Bunlara ek olarak, entegrasyon değişkeni kendi gecikmeli değerlerinden pozitif etkilenmektedir. Buradan hareketle, entegrasyon olgusunun kendini besleyen bir olgu olduğunu söyleyebiliriz - vice versa.
Makale Geçmişi:

Iletilen Tarih:

29 Mayıs 2020

Kabul Tarihi:

10 Mart 2021

Jel Kodlart:

G15, F36, G01

Anahtar Kelimeler:

Entegrasyon,

Segmentsyon, Hisse

Senedi Piyasalarl,

OECD Ülkeleri,

Finansal Kriz

Önerilen Alıntı: Çayır, M. (2021). OECD Ülkeleri Hisse Senedi Piyasaları Arasındaki Dinamik Entegrasyon ve Segmentasyon. Sivas Cumhuriyet Üniversitesi İktisadi ve İdari Bilimler Dergisi, 22(1), 196-212.

${ }^{1}$ Dr. Öğr. Üyesi, Mustafa ÇAYIR, Artvin Çoruh Üniversitesi, Uygulamalı Bilimler Yüksekokulu, Bankacılık ve Finans Bölümü, mustafacayir@artvin.edu.tr,_ORCID ID: 0000-0001-8744-631X 


\section{OECD ÜLKELERİ HISSE SENEDİ PIYYASALARI ARASINDAKİ DINNAMIKK ENTEGRASYON VE SEGMENTASYON}

\section{INTRODUCTION}

Integration of financial markets is substantial for the real and financial markets to fully function and accurately. Also, economic and financial integration has got a trade creation effect. So, economic and financial integration affects the wealth of nations positively. And, due to the reasons such as trade liberalisation, increased capital mobility, globalisation, technological progress and the decrease in transaction costs, its believed that national stock markets and capital markets are going to become more integrated and moved jointly over time. For instance, (Eken, 1984) shows that the liberalisation of capital flows in and out of Japan has increased the level of liaising in the Japanese financial system with the rest of the world. But, despite the beliefs and domination of the studies that support integrated economies, some studies support the integration of the markets include (Tse, 1998), (Collins and Abrahamson, 2004), (Bae et al., 2004), (Jong and Roon, 2005), (Piesse and Hearn, 2005), (Chi et al., 2006), (Georgoutsos and Migiakis, 2007), (Yi and Tan, 2009), (Shi et al., 2010), (Jarrett et al., 2013), (Wang et al., 2013), (Kim et al., 2015) and (Boamah et al., 2016) while others reach conclusions that the direction of segmentation like (Jorion and Schwarts, 1986), (Bodurtha Jr., 1986) and (Bodenhorn, 1992). So, there isn't any consensus about integration or segmentation of the markets in the economic literature.

On the side of moving jointly of financial, capital and equity markets, (Neal, 1987) concludes that Amsterdam and London's stock markets move together from 1723 on. (Phylaktis and Ravazzolo, 2002) find a high level of financial liaison in Pacific-Basin countries. (Pukthuanthong and Roll, 2009) derive a new integration measure and show that a marked increase in moving together among the country indexes. In the Baltics, (Deltuvaite, 2015) finds that global integration of Estonian and Lithuanian stock markets is a higher level in comparison with the Latvian market, although the degree of international integration of these markets is low in general. It is revealed by (Mellado and Escobari, 2015) that the Chilean, Colombian and Peruvian markets liaise with each other. (Komatsubara et al., 2017) investigate the integration of East Asian equity markets between 1995 and 2013. And, the study demonstrates that the level of linkage among China and other East Asian countries go up since 2007. The spillover of volatility among ten stock indices has been investigated by (Gursoy and Govdere, 2020). They state that there is a volatility spillover between stock indices.

On the side of segmentation of financial, capital and equity markets, (Jorion and Schwarts, 1986) examine whether integration and segmentation of the Canadian equity market relative to the US. And, the paper reaches a conclusion that rejection of integration. And (Bodenhorn, 1992) examines financial linkage in the U.S. comparatively pre-first world war period between the postfirst world war period. The paper concludes that the level of linkage of markets is higher in prefirst world war period than the post-first world war period. So, the results of (Bodenhorn, 1992) that there is a segmentation between the markets in time.

Some studies reach more complicated results than others about financial market integration. The linkage between Canadian and U.S. stock markets examined by (Mittoo, 1992) provides evidence segmentation in 1977-81 subperiod but integration in 1982-6 subperiod. It is investigated by (Valadkhani and Chancharat, 2007) that the existence of cointegration and causality between the stock market price indices of Thailand and its major trade partners. And, the investigation cannot find any linkage between stock prices of Thailand and the partners in the long-run, but it detects a positive relationship between stock prices of Thailand and its partners in the short-run. (Chambet and Gibson, 2008) examine the financial integration of emerging markets. The examination shows that the validity of segmentation in emerging markets. And the level of 
integration has decreased during the financial crises of the 1990s. Also, the examination states countries with a diversified trade structure have less integrated financial markets. (Chen et al., 2014) focus on stock market integration between the frontier and leading markets. The study reaches the results that population growth, industry value, interest rate, tax rate, and tariff of frontier markets and energy, gross national income, the stock traded value, and high-technology exports of leading markets influence the integration between both markets. The next study, (Bae and Zhang, 2015) which examining stock markets integration in emerging markets conclude that negative relation between stock market return and integration of the markets to global markets during the 2008 financial crisis. (Gal, 2015) shows that the local dynamics of a country or a region dominate the markets despite the internationalisation of the markets.

An investigation made by (Vithessonthi and Kumarasinghe, 2016) focuses on the relationship between stock market integration and financial development and international trade integration. The investigation alleges that progress in the financial sector of a country has a positive effect on its stock market integration. And also, a country's international trade linkage does not influence its stock market integration in Asia. (Alotaibi and Mishra, 2017) develop an index of global integration in finance. Then, trade openness, financial market development, turnover and oil revenue impact on stock markets integration of Gulf Cooperation Council countries positively according to the index and the paper.

At this framework, the purpose of this study is to investigate the dynamic integration and segmentation of OECD countries with each other. And, this study aims to contribute that examining of equity market integration between all of the OECD countries together as first to the economic literature. Then, it is targeted by us that this paper is rare research considering the period of the mortgage crisis and being intertemporal. In this context, econometric model, preliminary findings and dataset used in this study will be presented in the next section. Subsequently, it will be focused on method of analysis used in the estimation and the empirical results in the third section. And, the final section includes refined results revealed by the study.

\section{ECONOMETRIC MODEL, DATASET, AND PRELIMINARY FINDINGS}

I establish a model in the study to reveal the effects of time, the first difference of the independent variable, and the mortgage crisis on the Segmentation.

The model is as follows:

$$
\text { Segmentation }=\text { Constant }+\beta_{1} \text { (Time Dummy) }+\beta_{2}(\text { Crisis Dummy })+
$$

$\beta_{3}$ (L. Segmentation) $+\varepsilon$

Before the explanations of the variables in the model, giving some information about the dataset would be better. Within this scope, the dataset used in the study covers 2000:01 - 2018:12 period and it consists of monthly observations.

The Segmentation is measured as the variance of the stock price index returns of OECD members for each month in the study. So, the variance of the stock price indexes returns or segmentation is described as reciprocal of integration. And then the level of integration decrease when the variance values of the stock price index or the level of segmentation increase. And L. Segmentation is the one lagged values of the Segmentation. It is included in the model to reveal whether past values of the segmentation can affect the current integration of the equity markets 


\section{OECD ÜLKELERI HISSE SENEDI PIYYASALARI ARASINDAKI DINAMIK ENTEGRASYON VE SEGMENTASYON}

among the OECD Countries, or not. Stock price index data of OECD countries were drawn from the website of the OECD database.

The time dummy variable is starting from "1" in the first month, increasing one by one, and finishing "227" in the last month. It is used in the model to measure the effects of time on the integration of stock markets. The crisis dummy variable is consist of 1 and 0 . It takes values of "1" during the 2008 mortgage crisis period that between 2007:12 and 2009:06, and " 0 " for the other months.

The time path of the integration is located at the figure below. It consists of ten pieces of times of the variance values averages of monthly observations of stock price index returns for relevant each year. As seen from the figure, the level of segmentation has got a negative trend line that is the dashed line.

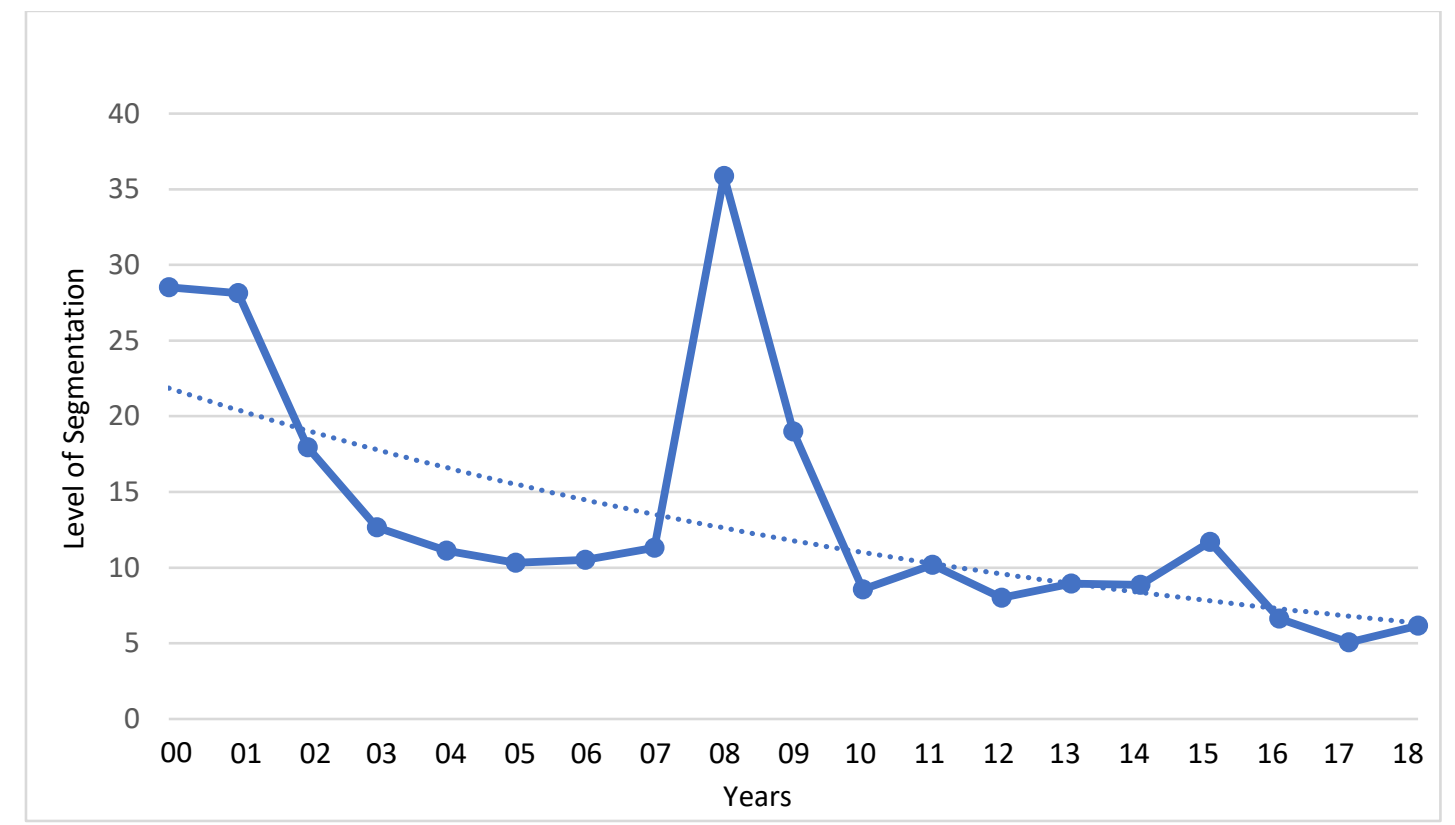

Figure 1: Time Path of the Segmentation

So, when we look at the figure, we can say that the equity markets of OECD countries are more integrated with each other in the course of time for the 2000-2018 period. And, there is no abnormal observation about the integration of equity markets at the relevant period except the time of mortgage crisis. On the other hand, the course of segmentation during the Mortgage Crisis takes place figure below. 
Mustafa ÇAYIR, 2021 Cilt: 22, Sayı:1, ss. 196-212.

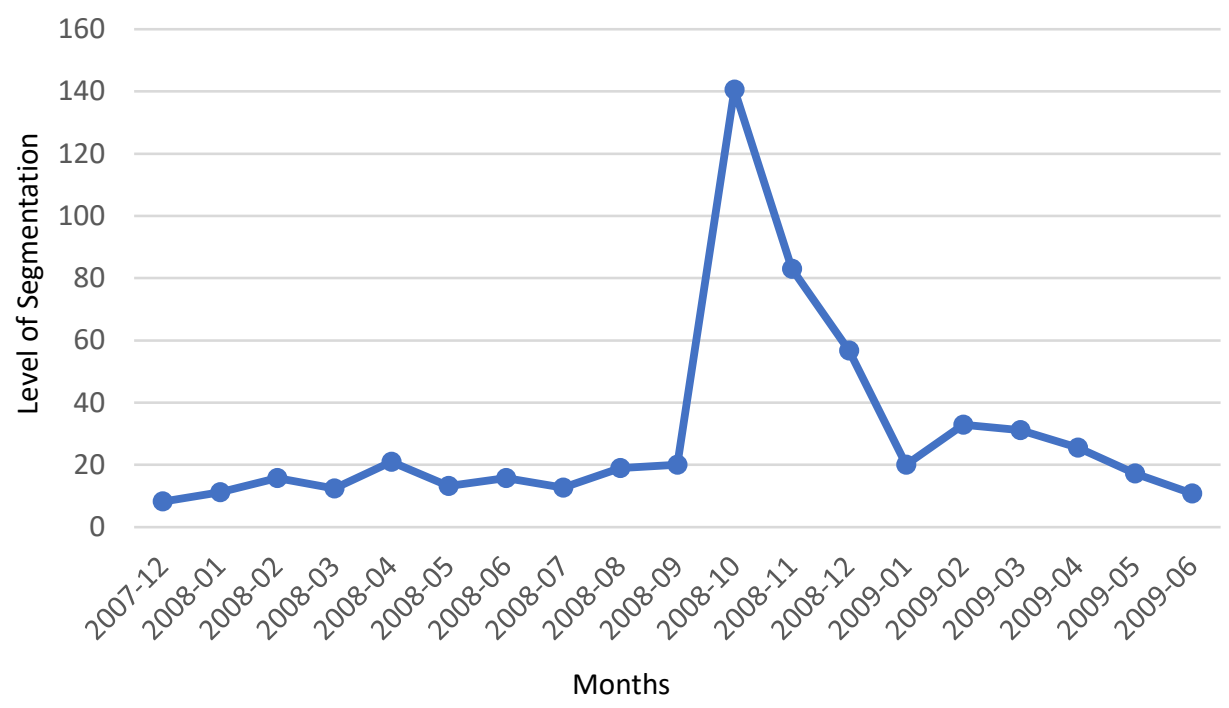

Figure 2: Course of Segmentation During the Mortgage Crisis

The figure above consists of ten pieces of times of variance values of monthly observations of stock price index returns of OECD Countries. It starts at 2007:12 and finishes at 2009:06 when is the period of the Mortgage crisis. The segmentation level jumps upward about from "20" to "140" at 2008:10 when at the very time of the bankruptcy of Lehman Brothers. Then, the degree of segmentation decreases, gradually, to about old values or before levels of Lehman shock by the time of 2009:01. So, it seems clear from the figure that the 2008 Mortgage crisis affected the equity market integration of OECD countries negatively.

It is taken ten pieces of times of the segmentation values, because of to be more understandable of both figures. There is no difference between the original values and their ten pieces of times values, and also no drawback in scientifically.

\section{METHOD OF ANALYSIS AND THE EMPIRICAL RESULTS}

In this section, first of all, I present the summary statistics of the segmentation data between 2000:01 and 2018:12 in the table below.

Table 1: Summary Statistics of Segmentation

\begin{tabular}{|l|c|l|l|l|l|}
\hline Variable & Observation & Mean & Std. Dev. & Min & Max \\
\hline Segmentation & 227 & 0,001369 & 0,001307 & 0,000223 & 0,014058 \\
\hline
\end{tabular}

Primarily, the model estimated with the method of ordinary least square (OLS). And, diagnostic tests of this regression are examined as well. Accordingly, while the F statistics show 


\section{OECD ÜLKELERI HISSE SENEDI PIYYSALARI ARASINDAKİ DINAMIK ENTEGRASYON VE SEGMENTASYON}

that there is no specification error in the model, the normality test ${ }^{2}$ reveals that the residuals of the independent variable (segmentation) have got a form of non-normal distribution. Also, serial correlation (autocorrelation) $)^{3}$ and heteroscedasticity ${ }^{4}$ are tested after the estimation process of the model. So, there is no serial correlation while White test rejects homoscedasticity in almost $5 \%$ statistically significant level in the estimation.

At this framework, it is necessary that employ a robust econometric method to non-normal distribution and heteroscedasticity in the regression. So, I use feasible generalized least square (FGLS) in the estimation process of the model. Both the ordinary least square and feasible generalized least square estimations' results take place in the table below, to compare both results.

Table 2: The Results of OLS and FGLS Estimations

\begin{tabular}{|c|c|c|c|c|c|}
\hline \multirow{3}{*}{$\begin{array}{l}\text { Segmentation } \\
\text { Constans }\end{array}$} & \multicolumn{2}{|l|}{ OLS } & \multicolumn{3}{|l|}{ FGLS } \\
\hline & \multirow{2}{*}{$\begin{array}{l}\text { Coef. (Prob) } \\
\begin{array}{l}0,00103 * * * \\
(0,00)\end{array}\end{array}$} & Std. Err. $(t$ - value $)$ & \multirow{2}{*}{$\begin{array}{l}\text { Coef. (Prob) } \\
\begin{array}{l}0,001421 * * * \\
(0,00)\end{array}\end{array}$} & \multicolumn{2}{|c|}{ Std. Err. $(t$ - value $)$} \\
\hline & & $0,000179 \quad(5,74)$ & & 0,00025 & $(5,68)$ \\
\hline Time Dummy & $\begin{array}{l}-0,000004 * * * \\
(0,00)\end{array}$ & $\begin{array}{l}0,000001 \\
(-3,244029)\end{array}$ & $\begin{array}{l}-0,000005 * * * \\
(0,00)\end{array}$ & $\begin{array}{c}0,000001 \\
(-4,97)\end{array}$ & \\
\hline Crisis Dummy & $\begin{array}{l}0,000879 * * * \\
(0,00)\end{array}$ & $0,000254 \quad(3,457917)$ & $\begin{array}{l}0,001508^{*} \\
(0,09)\end{array}$ & 0,000884 & $(1,7)$ \\
\hline Segmentation (-1) & $\begin{array}{l}0,474488 * * * \\
(0,00)\end{array}$ & $0,058433 \quad(8,120203)$ & $\begin{array}{l}0,26888 * * * \\
(0,00)\end{array}$ & 0,078812 & $(3,41)$ \\
\hline F Statistics (F Prob) & \multicolumn{2}{|c|}{$58,04 \quad(0,0000)$} & \multicolumn{3}{|c|}{$183,18 \quad(0,0000)$} \\
\hline R - Sq. (Adj. R - Sq.) & \multicolumn{2}{|c|}{$0,4396 \quad(0,432)$} & \multicolumn{3}{|c|}{$0,7451 \quad(0,741)$} \\
\hline
\end{tabular}

Not: $* * * ", " * * "$ and "*" symbols indicate that, respectively, $1 \%, 5 \%$ and $10 \%$ statistical significance of the coefficients. Segmentation is the independent variable of the regressions at the table above.

All estimated coefficient is statistically significant at the $1 \%$ level in both regressions except the coefficient of the crisis dummy variable in the FGLS estimation. As it could be seen from Table 2, the crisis dummy variable's coefficient is statistically significant at the $10 \%$ level in the FGLS.

On the other hand, the mathematical signs of the whole coefficients are in line with theoretical expectations. Within this scope, the integration level of equity markets among OECD countries builds up over time as expected. And then, the 2008 mortgage crisis causes that

\footnotetext{
${ }^{2}$ The results of the Jarque - Bera normality test are presented in the appendix of the study.

${ }^{3}$ Breusch - Godfrey (LM) test results are indicated in the appendix of the study.

4 The results obtained from the White test are reported in the appendix of the study.
} 
Mustafa ÇAYIR, 2021 Cilt: 22, Sayı:1, ss. 196-212.

decreasing the level of integration. In other words, the global financial crises affect the movements of equity price indexes among the OECD countries to the direction of segmentation.

Finally, an increase in the level of segmentation among the equity markets of OECD countries raises the level of segmentation of the subsequent month. So, the integration conjuncture feeds integration, while the conjuncture of segmentation supports segmentation in the equity markets of OECD countries for the examined period in the study. 


\section{OECD ÜLKELERI HISSE SENEDI PIYASALARI ARASINDAKI DINAMIK ENTEGRASYON VE SEGMENTASYON}

\section{CONCLUDING REMARKS}

The dynamic integration and segmentation among the equity markets of OECD countries have been investigated in this study. Within this scope, a model has been established so as to reveal the navigation of the integration level in the course of time, the behaviour of the integration during the 2008 mortgage crises and the response of the integration to the own lagged values. Also, the study covers the period between 2000:01 and 2018:12.

It can be expected that the integration level in the equity markets must increase owing to progress in technology, transaction costs, information technologies and communication instruments in time. The results obtained from this study satisfy the expectations. Hereunder, the integration level in the equity markets of OECD countries is affected by the elapsing positively. On the other side, the 2008 mortgage crisis influence the level of integration negatively. And then, the current level of integration raises when the previous month's level of integration goes up.

At this framework, on the one hand, reached results about the time variable in this study coincide the researches that obtain integration sided results like (Neal, 1987), (Phylaktis and Ravazzolo, 2002), (Deltuvaite, 2015) and (Komatsubara et al., 2017). And obtained evidence about the Mortgage Crisis variable in this paper look supportive to papers that conclude the validity of segmentation such as (Jorion and Schwarts, 1986) and (Bodenhorn, 1992). On the other hand, when our results evaluated with all components, they corroborate the studies that reach complicated results about integration and segmentation such as (Mittoo, 1992), (Valadkhani and Chancharat, 2007), (Chen et al., 2014) and (Gal, 2015).

Finally, the following studies in this field may contribute to the relevant literature about the different country groups, corporations and organisations or compare the level of integration among the groups, corporations and organisations. 


\section{REFERENCES}

Alota1b1, A. R., \& Mishra, A. V. (2017). Time Varying International Financial Integration for GCC Stock Markets. The Quarterly Review of Economics and Finance, 63, 66-78. http://Dx.Doi.Org/10.1016/J.Qref.2016.03.001.

Bae, K. H., Chan, K., \& Ng, A. (2004). Investibility and Return Volatility. Journal of Financial Economics, 71,239 - 263. Https://Doi.Org/10.1016/S0304-405X(03)00166-1.

Bae, K. H., \& Zhang, X. (2015). The Cost of Stock Market Integration in Emerging Markets. Asia - Pasific Journal Of Financial Studies, 44, 1 - 23. Https://Doi.Org/10.1111/Ajfs.12079.

Boamah, N. A., Watts, E. J., \& Loudon, G. (2016). Investigating Temporal Variation in the Global and Regional Integration of African Stock Markets. Journal of Multinational Financial Management, 36, 103 - 118. Https://Doi.Org/10.1016/J.Mulfin.2016.06.001.

Bodenhorn, H. (1992). Capital Mobility and Financial Integration in Antebellum America. The Journal of Economic History, 52 (3), 585 - 610. Https://Www.Jstor.Org/Stable/2122886.

Bodurtha Jr., J. N. (1986). Integration vs. Segmentation in the Canadian Stock Market: Discussion. The Journal of Finance, 41 (3), 614 - 616. Https://Www.Jstor.Org/Stable/2328490.

Chambet, A., \& Gibson, R. (2008). Financial Integration, Economic Instability and Trade Structure in Emerging Markets. Journal of International Money and Finance, 27, 654-675. Https://Doi.Org/10.1016/J.Jimonfin.2008.02.007.

Chen, M. P., Chen, P. F., \& Lee, C. C. (2014). Frontier Stock Market Integration and the Global Financial Crisis. North American Journal of Economics and Finance, 29, 84-103. Https://Doi.Org/10.1016/J.Najef.2014.05.004.

Ch1, J., L1, K., \& Young, M. (2006). Financial Integration in East Asian Equity Markets. Pacific Economic Review, 11 (4): 513 - 526. Https://Doi.Org/10.1111/J.1468-0106.2006.00332.X.

Collıns, D., \& Abrahamson, M. (2004). African Equity Markets and the Process of Global Financial Integration. South African Journal of Economics, 72 (4), 658-683. Http://Onlinelibrary.Wiley.Com/Doi/10.1111/J.1813-6982.2004.Tb00129.X/Pdf.

Deltuvarte, V. (2015). An Empirical Investigation of the Baltic Stock Markets Global Integration. Procedia-Social and Behavioral Sciences, 213, 430-435. Https://Doi.Org/10.1016/J.Sbspro.2015.11.562.

Eken, S. (1984). Integration of Domestic and International Financial Markets: The Japanese Experience. Palgrave Macmillan Journals, $31 \quad$ (3), 499-548. Http://Www.Jstor.Org/Stable/3866752.

Gal, Z. (2015). Financial Globalisation and the Spatial Limitations of the Financial - Monetary Integration in the Euro Area. Public Finance Quarterly, 60 (1), 104-124. Https://Www.Researchgate.Net/Publication/278197355.

Georgoutsos, D., \& Migiakıs, P. M. (2007). European and International Bond Markets Integration. World Academy of Science, Engineering and Technology, 30, 52-57. Https://Pdfs.Semanticscholar.Org/C10a/8959173128a178093ae7ccc2db30c59460bb.Pdf.

Gursoy, S., \& Govdere, B. (2020). Uluslararası Pay Piyasaları Arasındaki Getiri ve Volatilite Yayılımı: Gelişmiş ve Gelişmekte Olan Üzerine Bir İnceleme. Süleyman Demirel 


\section{OECD ÜLKELERI HISSE SENEDI PIYASALARI ARASINDAKİ DINAMIK ENTEGRASYON VE SEGMENTASYON}
Üniversitesi
Vizyoner
Dergisi,
11
(27),
498-513.

Https://Doi.Org/10.21076/Vizyoner.660976.

Jarrett, J., Klein, A. F., \& Kyper, E. (2013). Association Between Asian Equity Markets and Western Markets: Evidence from the Indexes of Equity Markets. Asian Journal of Empirical Research, 3(8): 972-989. Https://Digitalcommons.Uri.Edu/Cgi/Viewcontent.Cgi?Referer=Https://Www.Google.Co $\underline{\mathrm{m} / \& H t t p s r e d i r}=1 \&$ Article $=1025 \&$ Context=Cba_Facpubs.

Jong, F. D., \& Roon, F. A. D. (2005). Time - Varying Market Integration and Expected Returns in Emerging Markets. Journal of Financial Economics, 78, 583-613. https://Doi.Org/10.1016/J.Jfineco.2004.10.010.

Jorıon, P., \& Schwartz, E. (1986). Integration vs. Segmentation in the Canadian Stock Market. The Journal of Finance, 41 (3), 603 - 614. Https://Www.Jstor.Org/Stable/2328489.

Kım, S. W., Kım, Y. M., \& Cho1, M. J. (2015). Asia - Pacific Stock Market Integration: New Evidence By Incorporating Regime Changes. Emerging Markets Finance and Trade, 51 (4), 68 - 88. Https://Doi.Org/10.1080/1540496X.2015.1026726.

Komatsubara, T., Okımoto, T., \& Tatsumı, K. I. (2017). Dynamics of Integration in East Asian Equity Markets. Journal of the Japanese and International Economies, 45, 37 - 50. Https://Doi.Org/10.1016/J.Jjie.2017.07.002.

Mellado, C., \& Escobar1, D. (2015). Virtual Integration of Financial Markets: A Dynamic Correlation Analysis of the Creation of the Latin American Integrated Market. Applied Economics, 47 (19), 1956 - 1971. Https://Doi.Org/10.1080/00036846.2014.1002892.

Mittoo, U. R. (1992). Additional Evidence on Integration in the Canadian Stock Market. The Journal of Finance, 47 (5), 2035 - 2054. Http://Www.Jstor.Org/Stable/2329009.

Neal, L. (1987). The Integration and Efficiency of the London and Amsterdam Stock Markets in the Eighteenth Century. The Journal of Economic History, 47 (1), 97 - 115. Http://Www.Jstor.Org/Stable/2121941.

Phylaktıs, K., \& Ravazzolo, F. (2002). Measuring Financial and Economic Integration with Equity Prices in Emerging Markets. Journal of International Money and Finance, 21, 879 - 903. Https://Doi.Org/10.1016/S0261-5606(02)00027-X.

P1esse, J., \& Hearn, B. (2005). Regional Integration of Equity Markets in Sub - Saharan Africa. South African Journal Of Economics, 73 (1), 36-52. Https://Doi.Org/10.1111/J.18136982.2005.00003.X.

Pukthuanthong, K., \& Roll, R. (2009). Global Market Integration: An Alternative Measure and Its Application. Journal Of Financial Economics, 94, 214-232. Https://Doi.Org/10.1016/J.Jfineco.2008.12.004.

Sh1, J., B1lson, C., Powell, J. G., \& Wigg, J. (2010). Foreign Direct Investment and International Stock Market Integration. Australian Journal of Management, 35 (3), 265-290. Https://Doi.Org/10.1177/0312896210384680.

Tse, Y. (1998). International Linkages in Euromark Futures Markets: Information Transmission and Market Integration. The Journal of Futures Markets, 18 (2), 129-149. Https://Doi.Org/10.1002/(SICI)1096-9934(199804)18:2<129::AID-FUT1>3.0.CO;2-K. 
Valadkhan1, A., \& Chancharat, S. (2007). Dynamic Linkage Between Thai and International Stock Markets. Journal of Economic Studies, 35 (5), 425-441. Https://Pdfs.Semanticscholar.Org/493c/1b5cc2f0475ab245e5ff457cebdd27beb493.Pdf.

Vithessonth1, C., \& Kumarasinghe, S. (2016). Financial Development, International Trade Integration, and Stock Market Integration: Evidence from Asia. Journal of Multinational Financial Management, 35, 79 - 92. Http://Dx.Doi.Org/10.1016/J.Mulfin.2016.03.001.

Wang, M. C., Fang, M., \& Ye, J. K. (2013). Financial Integration of Large - and Small - Cap Stocks in Emerging Markets. Emerging Markets Finance and Trade, 49 (4), 17-31. Https://Doi.Org/10.2753/REE1540-496X4905S402.

Y1, Z., \& Tan, S. L. (2009). An Empirical Analysis of Stock Market Integration: Comparison Study of Singapore and Malaysia. Singapore Economic Review, 54 (2), 217-232. Https://Doi.Org/10.1142/S021759080900332X. 


\section{OECD ÜLKELERI HISSE SENEDI PIYYASALARI ARASINDAKİ DINAMIK ENTEGRASYON VE SEGMENTASYON}

\section{CONFLICT OF INTEREST}

There is no conflict of interest.

\section{APPENDIX}

Appendix 1: The Results of the Jarque - Bera Normality Test

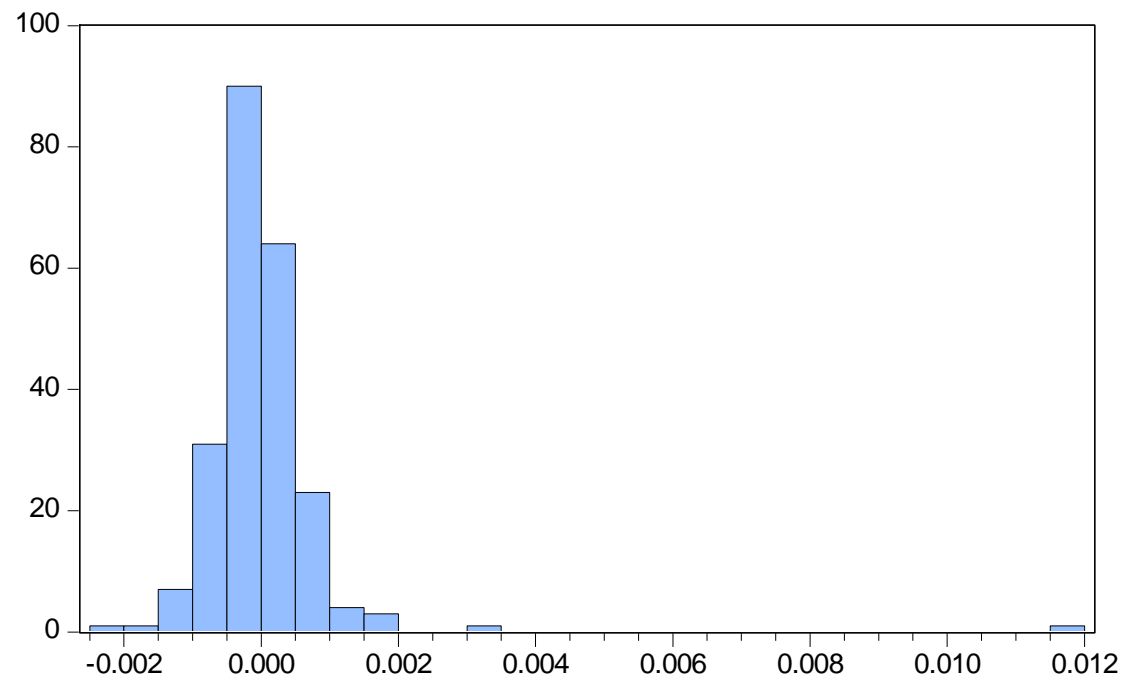

\begin{tabular}{lr}
\multicolumn{2}{l}{ Series: Residuals } \\
Sample 2000M03 2018M12 \\
Observations 226 \\
Mean & $1.92 \mathrm{e}-20$ \\
Median & $-6.67 \mathrm{e}-05$ \\
Maximum & 0.011565 \\
Minimum & -0.002226 \\
Std. Dev. & 0.000965 \\
Skewness & 7.785507 \\
Kurtosis & 93.08630 \\
& \\
Jarque-Bera & 78704.48 \\
Probability & 0.000000
\end{tabular}

Appendix 2: The Results of Breusch - Godfrey (LM) Autocorrelation Test Breusch-Godfrey Serial Correlation LM Test:

F-statistic

0.239516

Prob. $\mathrm{F}(2,220)$

0.7872

Obs*R-squared

0.491027

Prob. Chi-Square(2)

0.7823

Test Equation:

Dependent Variable: RESID

Method: Least Squares

Date: 06/29/19 Time: 18:13

Sample: 2000M03 2018M12

Included observations: 226

Presample missing value lagged residuals set to zero. 
Mustafa ÇAYIR, 2021 Cilt: 22, Sayl:1, ss. 196-212.

\begin{tabular}{lcccc} 
Variable & Coefficient & Std. Error & t-Statistic & Prob. \\
\hline \hline C & 3.77E-05 & 0.000396 & 0.095196 & 0.9242 \\
TIME_D & $-1.30 \mathrm{E}-07$ & $1.64 \mathrm{E}-06$ & -0.079210 & 0.9369 \\
C_D & $2.19 \mathrm{E}-05$ & 0.000362 & 0.060578 & 0.9518 \\
VAR(-1) & -0.017867 & 0.178980 & -0.099825 & 0.9206 \\
RESID(-1) & 0.001152 & 0.190039 & 0.006062 & 0.9952 \\
RESID(-2) & 0.051017 & 0.106499 & 0.479036 & 0.6324 \\
\hline \hline & & & & \\
R-squared & 0.002173 & Mean dependent var & $1.92 \mathrm{E}-20$ \\
Adjusted R-squared & -0.020505 & S.D. dependent var & 0.000965 \\
S.E. of regression & 0.000975 & Akaike info criterion & -11.00267 \\
Sum squared resid & 0.000209 & Schwarz criterion & -10.91186 \\
Log likelihood & 1249.302 & Hannan-Quinn criter. & -10.96603 \\
F-statistic & 0.095806 & Durbin-Watson stat & 1.986315 \\
Prob(F-statistic) & 0.992776 & & & \\
\hline \hline
\end{tabular}

Appendix 3: The Results of White Heteroscedasticity Test Heteroskedasticity Test: White

\begin{tabular}{cccc}
\hline \hline F-statistic & 1.968625 & Prob. F(8,217) & 0.0516 \\
Obs*R-squared & 15.29232 & Prob. Chi-Square(8) & 0.0537 \\
Scaled explained SS & 679.4032 & Prob. Chi-Square(8) & 0.0000 \\
\hline \hline
\end{tabular}

Test Equation:

Dependent Variable: RESID^2

Method: Least Squares 


\section{OECD ÜLKELERI HISSE SENEDI PIYYASALARI ARASINDAKİ DINAMIK ENTEGRASYON VE SEGMENTASYON}

Date: 06/29/19 Time: 18:17

Sample: 2000M03 2018M12

Included observations: 226

Collinear test regressors dropped from specification

\begin{tabular}{|c|c|c|c|c|}
\hline Variable & Coefficient & Std. Error & t-Statistic & Prob. \\
\hline $\mathrm{C}$ & $9.98 \mathrm{E}-08$ & 4.39E-06 & 0.022707 & 0.9819 \\
\hline TIME_D^2 & $-1.61 \mathrm{E}-12$ & $2.20 \mathrm{E}-10$ & -0.007309 & 0.9942 \\
\hline TIME_D*C_D & $4.01 \mathrm{E}-07$ & 4.33E-07 & 0.925328 & 0.3558 \\
\hline TIME_D*VAR(-1) & $-1.24 \mathrm{E}-06$ & $1.65 \mathrm{E}-05$ & -0.075287 & 0.9401 \\
\hline TIME_D & $4.69 \mathrm{E}-10$ & $6.55 \mathrm{E}-08$ & 0.007153 & 0.9943 \\
\hline C_D $D^{\wedge} 2$ & $-3.09 \mathrm{E}-05$ & $4.28 \mathrm{E}-05$ & -0.722264 & 0.4709 \\
\hline C_D*VAR(-1) & -0.001104 & 0.002552 & -0.432707 & 0.6657 \\
\hline $\operatorname{VAR}(-1)^{\wedge} 2$ & 0.002808 & 0.194969 & 0.014401 & 0.9885 \\
\hline $\operatorname{VAR}(-1)$ & 0.000234 & 0.001857 & 0.126255 & 0.8996 \\
\hline $\mathrm{R}$-squared & 0.067665 & \multicolumn{2}{|c|}{ Mean dependent var } & $9.27 \mathrm{E}-07$ \\
\hline Adjusted R-squared & 0.033293 & \multicolumn{2}{|c|}{ S.D. dependent var } & 8.91E-06 \\
\hline S.E. of regression & $8.76 \mathrm{E}-06$ & \multicolumn{2}{|c|}{ Akaike info criterion } & -20.41276 \\
\hline Sum squared resid & $1.67 \mathrm{E}-08$ & \multicolumn{2}{|c|}{ Schwarz criterion } & -20.27654 \\
\hline Log likelihood & 2315.642 & \multicolumn{2}{|c|}{ Hannan-Quinn criter. } & -20.35779 \\
\hline F-statistic & 1.968625 & \multicolumn{2}{|c|}{ Durbin-Watson stat } & 1.996982 \\
\hline Prob(F-statistic) & 0.051614 & & & \\
\hline
\end{tabular}




\section{EXTENDED ABSTRACT}

Integration of financial markets is substantial for the real and financial markets to function fully and accurately. Also, economic and financial integration has got a trade creation effect. So, economic and financial integration affects the wealth of nations positively. And, due to the reasons such as trade liberalization, increased capital mobility, globalization, technological progress and the decrease in transaction costs, it is believed that national stock markets and capital markets are going to become more integrated and move jointly over time. In this scope, the purpose of the present study is to explore the direction, in which the dependency among the equity markets of the Organization for Economic Co-operation and Development countries, has progressed over time and how it was affected by the 2008 subprime mortgage global financial crisis. Additionally, to the knowledge of the researcher, this is the first study aiming to contribute to the related literature by examining equity market integration between all of the OECD countries. moreover, this paper might be considered as a rare research considering the period of the 2008 mortgage financial crisis and being intertemporal. Within this framework, integration and segmentation among the equity markets of OECD countries have been investigated. The segmentation is measured as the variance of the stock price index returns of OECD members for each month in the study. So, the variance of the stock price indexes returns, or segmentation is described as reciprocal of integration.

The time dummy variable is starting from "1" in the first month, increasing one by one, and finishing "227" in the last month. It is used in the model to measure the effects of time on the integration of stock markets. The crisis dummy variable consists of 1 and 0 . It takes values of "1" during the 2008 mortgage crisis period that between 2007: 12 and 2009: 06, and "0" for the other months. The study covers $2000: 01-2018: 12$ period and Stock price index data of OECD countries were drawn from the website of the OECD database. And the data consists of monthly observations.

As Preliminary findings, it can be said that the equity markets of OECD countries are more integrated with each other in the course of time for the $2000-2018$ period. Moreover, there is no abnormal observation about the integration of equity markets at the relevant period except the time of mortgage crisis. The segmentation level jumps upward from about "20" to "140" at 2008: 10 at the very time of the bankruptcy of Lehman Brothers. Then, the degree of segmentation decreased, gradually, to the ones close to previous values or before the levels of Lehman Brothers shock by the time of 2009: 01. So, it can be concluded that the 2008 mortgage financial crisis affected the equity market integration of OECD countries.

The model was calculated with the method of ordinary least square (OLS). Diagnostic tests of this regression were also examined. Accordingly, while the F statistics showed that there was no specification error in the model, the normality test demonstrated that the residuals of the independent variable (segmentation) had a form of non-normal distribution. Also, serial correlation (autocorrelation) and heteroscedasticity were tested after the estimation process of the model. So, there was no serial correlation while White test rejected homoscedasticity in almost $5 \%$ statistically significant level in the estimation. So, the feasible generalized least square (FGLS) was employed in the estimation process of the model, because the feasible generalized least square was one of the robust econometric methods to non-normal distribution and heteroscedasticity. But, to compare both results, both the ordinary least square and feasible generalized least square estimations' results were utilized in the study. All estimated coefficient was statistically significant at the $1 \%$ level in 


\section{OECD ÜLKELERI HISSE SENEDI PIYYSALARI ARASINDAKI DINAMIK ENTEGRASYON VE SEGMENTASYON}

both regressions except the coefficient of the crisis dummy variable in the feasible generalized least square estimation. So, the 2008 subprime mortgage global financial crisis negatively affected the level of integration that the statistical significance of the effect is $10 \%$, while the passing of time influenced the integration level positively among the equity markets according to the obtained results in this study.

It can be expected that the integration level in the equity markets must increase owing to progress in technology, transaction costs, information technologies and communication instruments in time. Hereunder, the mathematical signs of the whole estimated coefficients are in line with theoretical expectations in the present study. Within this scope, the integration level of equity markets among the OECD countries built up over time as expected. So, the results obtained from this study satisfy the theoretical expectations. In addition, the current level of integration increased when the previous month's level of integration went up. So, the integration conjuncture stimulated integration, while the conjuncture of segmentation supported segmentation in the equity markets of OECD countries for the examined period in the study.

On the one hand, obtained results about the time dummy variable in this study are in parallel with the research that obtained integration sided results like (Neal, 1987), (Phylaktis and Ravazzolo, 2002), (Deltuvaite, 2015) and (Komatsubara et al., 2017). And obtained evidence about the 2008 mortgage financial crisis dummy variable in this paper looks supportive to the papers that conclude the validity of segmentation such as (Jorion and Schwarts, 1986) and (Bodenhorn, 1992). On the other hand, when our results are evaluated with all components, they corroborate with the studies that obtained complicated results about the integration and the segmentation such as (Mittoo, 1992), (Valadkhani and Chancharat, 2007), (Chen et al., 2014) and (Gal, 2015).

In conclusion, the following studies in this field may contribute to the relevant literature about the different country groups, corporations and organizations or compare the level of integration among the groups, corporations and organizations. 